\title{
KECERNAAN BAHAN KERING DAN BAHAN ORGANIK KULIT PISANG RAJA TERFERMENTASI DENGAN Rhizopus oligosporus DALAM RANSUM AYAM BROILER
}

\author{
Nabenus Wenda, F. R. Wolayan*, I. M. Untu, H. Liwe \\ Fakultas Peternakan Universitas Sam Ratulangi, Manado 95115
}

\begin{abstract}
ABSTRAK
Penelitian ini bertujuan untuk mengetahui kecernaan bahan kering dan bahan organik ransum yang menggunakan kulit pisang raja produk fermentasi dengan Rhizopus oligosporus pada ayam broiler. Penelitian ini dilakukan dengan menggunakan 20 ekor ayam broiler strain Arbor Acres CP. Strain 707 umur 5 minggu, dengan rataan berat badan \pm 1067 gram. Rancangan yang digunakan adalah: Uji-tstudent yang terdiri dari 2 perlakuan, masing-masing perlakuan terdiri atas 10 ekor ayam broiler sebagai ulangan. Ransum yang digunakan pada penelitian ini adalah: Tepung kulit pisang raja tanpa fermentasi dan produk fermentasi dengan kapang Rhizopus oligosporus. Hasil uji t-student menunjukkan bahwa kecernaan bahan kering tepung kulit pisang raja produk fermentasi berbeda sangat nyata $(\mathrm{P}<0.01)$ dibandingkan dengan tepung kulit pisang raja tanpa fermentasi. Kecernaan tepung kulit pisang sebelum fermentasi $62,32 \%$ dan setelah difermentasi menjadi $71,66 \%$ demikian juga dengan kecernaan bahan organik yaitu sebelum fermentasi $66,74 \%$ dan setelah difermentasi menjadi $73,0 \%$. Berdasarkan hasil dan pembahasan dapat disimpulkan bahwa penggunaan tepung kulit pisang raja produk fermentasi sebesar $8,55 \%$ dalam ransum memberikan hasil lebih baik terhadap kecernaan bahan kering dan bahan organik dibandingkan dengan tanpa fermentasi.
\end{abstract}

\footnotetext{
* Korespondensi (corresponding author Email: fenny-wolayang@unsrat.ac.id
}

memberikan hasil lebih baik terhadap kecernaan bahan kering dan bahan organik dibandingkan dengan tanpa fermentasi.

Kata Kunci: Kulit Pisang Raja, Fermentasi, Rhizopus oligosporus, Ayam Broiler.

ABSTRACT
DIGESTIBILITY OF DRY
MATTER AND ORGANIC MATTER
OF RAJA BANANA PEELS WITH
Rhizopus oligosporus FERMENTED IN
BROILER RATION. This study aims to
determine the digestibility of dry matter and
organic material rations using the peels of
banana Raja fermented with Rhizopus
oligosporus in broiler chickens. This
research was conducted using 20 broilers of
Arbor Acres CP. 707 Strain aged 5 weeks,
with an average body weight of \pm 1067
grams. The design used was: Student t-test
consisting of 2 treatments, each treatment
consisted of 10 broilers as a test. The rations
used in this study were: Raja Banana peels
flour without fermentation and fermented
products with Rhizopus oligosporus mold.
The t-student test results showed that the
digestibility of dry banana skin powder of
fermented Raja banana product was
significantly different (P<0.01) compared
to unripe fermented Raja banana flour
which was $62.32 \%$ to $71.66 \%$ as well as the
digestibility of organic matter ie from
66.74\% to $73.01 \%$. Based on the results and
discussion it can be concluded that the use
of raja banana skin peel flour $15 \%$
fermented product in the ration gives better


results to the digestibility of dry matter and organic matter compared to without fermentation.

Keywords: Raja Banana Peels, Fermentation, Rhizopus oligosporus, Broiler Chicken.

\section{PENDAHULUAN}

Broiler merupakan hasil rekayasa genetik yang telah mengalami seleksi, memiliki pertumbuhan yang cepat karena mampu memanfaatkan pakan secara efisien, dapat menghasilkan daging dalam waktu yang relatif singkat, karena memiliki kemampuan genetik untuk bertumbuh dengan cepat, yaitu 5-6 minggu dengan bobot badan sekitar 1,3-1,6 kg, dalam pemeliharaan ayam broiler biaya pakan mencapai $65-70 \%$ dari total biaya operasional (Oktaviana dan Maulida, 2010). Umumnya bahan pakan penyusun ransum ayam broiler bersaing dengan kebutuhan pangan, seperti jagung, tepung ikan, dan kacang kedele. Jumlah kebutuhan akan bahan-bahan ini lebih tinggi dari pada ketersediaannya, mengakibatkan bahan telah diimpor sehingga harga ransum menjadi relatif mahal, untuk mengatasinya maka perlu dimanfaatkan bahan penyusun ransum inkonvensional seperti limbah pertanian.

Salah satu limbah pertanian yang belum dimanfaatkan secara maksimal adalah kulit pisang raja. Kulit pisang raja mengandung protein $4,08 \%$ dan serat kasar $12,50 \%$ yang pemanfaatannya sebagai penyusum ransum unggas belum banyak digunakan karena nilai nutriennya rendah. Alternatif untuk meningkatkan kualitas nutrien adalah dengan cara fermentasi, sebab proses fermentasi dapat meningkatkan kualitas dari bahan asalnya. Fermentasi kulit pisang raja, menggunakan kapang Rhizopus oligosporus dengan dosis inokulum $0,4 \%$ serta lama fermentasi 96 jam dapat meningkatkan nilai gizi dengan penurunan persentase kandungan serat kasar sebesar $18.38 \%$ (Manorek et al., 2017). Tepung kulit pisang raja tanpa fermentasi dapat digunakan sebesar $15 \%$ sebagai pengganti jagung dalam ransum Broiler (Djapili et al., 2016). Untuk menguji kualitas pakan dilakukan uji biologis dengan mengukur kecernaan.

Tolok ukur menentukan kualitas atau mutu bahan pakan tidak cukup hanya melalui analisis kimiawi. Nilai nutrien bahan pakan sesungguhnya dapat diuji melalui pengujian biologis untuk mengetahui kualitas tersebut melalui pegujian kecernaan. Kecernaan adalah selisih antara zat makanan yang dikonsumsi dengan yang dieksresikan dalam feces dan dianggap terserap dalam saluran cerna. Jadi kecernaan merupakan pencerminan dari jumlah nutrisi dalam bahan pakan yang dapat dimanfaatkan oleh ternak. Tinggi rendahnya kecernaan bahan 
pakan memberikan arti seberapa besar bahan pakan itu mengandung zat-zat makanan dalam bentuk yang dapat dicerna dalam saluran pencernaan (Ismail, 2011). Pengukuran kecernaan suatu bahan pakan dapat dilihat diantaranya dari bahan kering dan bahan organik. Berdasarkan latar belakang tersebut maka telah dilakukan penelitian untuk mengetahui seberapa besar kecernaan bahan kering dan bahan organik ransum yang mengandung kulit pisang raja tanpa fermentasi dan produk fermentasi.

\section{MATERI DAN METODE PENELITIAN}

Penelitian ini telah dilaksanakan di kandang unggas Fakultas Peternakan Unsrat Manado, selama 2 minggu Tanggal, 17 Mei sampai dengan 30 Mei 2018. Penelitian ini menggunakan 20 ekor ayam broiler strain Arbor Acres CP. 707 umur 5 minggu terdiri dari 2 perlakuan, masingmasing perlakuan terdiri atas 10 ekor ayam broiler sebagai ulangan. Kandang yang digunakan pada penelitian yaitu kandang baterei berukuran $40 \times 30 \times 30 \mathrm{~cm}$, yang terdiri dari 20 unit kandang. Tiap kandang ditempatkan 1 ekor broiler. Tiap unit dilengkapi dengan tempat makan dan minum serta penampung ekskreta. Peralatan yang digunakan dalam penelitian ini adalah timbangan ohaus kapasitas 2.610 gram untuk menimbang ransum dan ekskreta, sprayer, wadah penampung ekskreta, kantong plastik, ember, sapu lidi, lampu pijar. Ransum yang digunakan pada penelitian ini yaitu kulit pisang raja tanpa fermentasi dan produk fermentasi dengan kapang Rhizopus oligosporus, jagung kuning, bungkil kelapa, dedak halus, tepung ikan, tepung kedele, serta topmix. Komposisi zat-zat makanan dan energi metabolis bahan pakan penyusun ransum tertera pada Tabel 1. Pada Tabel 2 mencantumkan komposisi bahan pakan ransum percobaan dan Tabel 3 komposisi zat-zat makanan dan energi metabolis ransum percobaan. Sebanyak 20 ekor broiler dibagi dalam 2 perlakuan dan masing-masing perlakuan terdiri dari 10 ekor broiler sebagai ulangan. Perlakuan adalah ransum yang mengandung tepung kulit pisang raja tanpa fermentasi dan kulit pisang raja fermentasi.

Sebelum penelitian dimulai, kandang dan peralatan yang akan digunakan dibersihkan dan lampu penerangan disiapkan dalam tiap unit kandang, dengan tahapan penelitian sebagai berikut: Tahap adaptasi sebanyak 20 ekor ayam broiler umur 5 minggu dibagi dalam 2 perlakuan terdiri dari 10 ulangan dan setiap ulangan ditempatkan 1 ayam 
Tabel 1. Komposisi Zat-zat Makanan dan Energi Metabolis Bahan Pakan Penyusun Ransum.

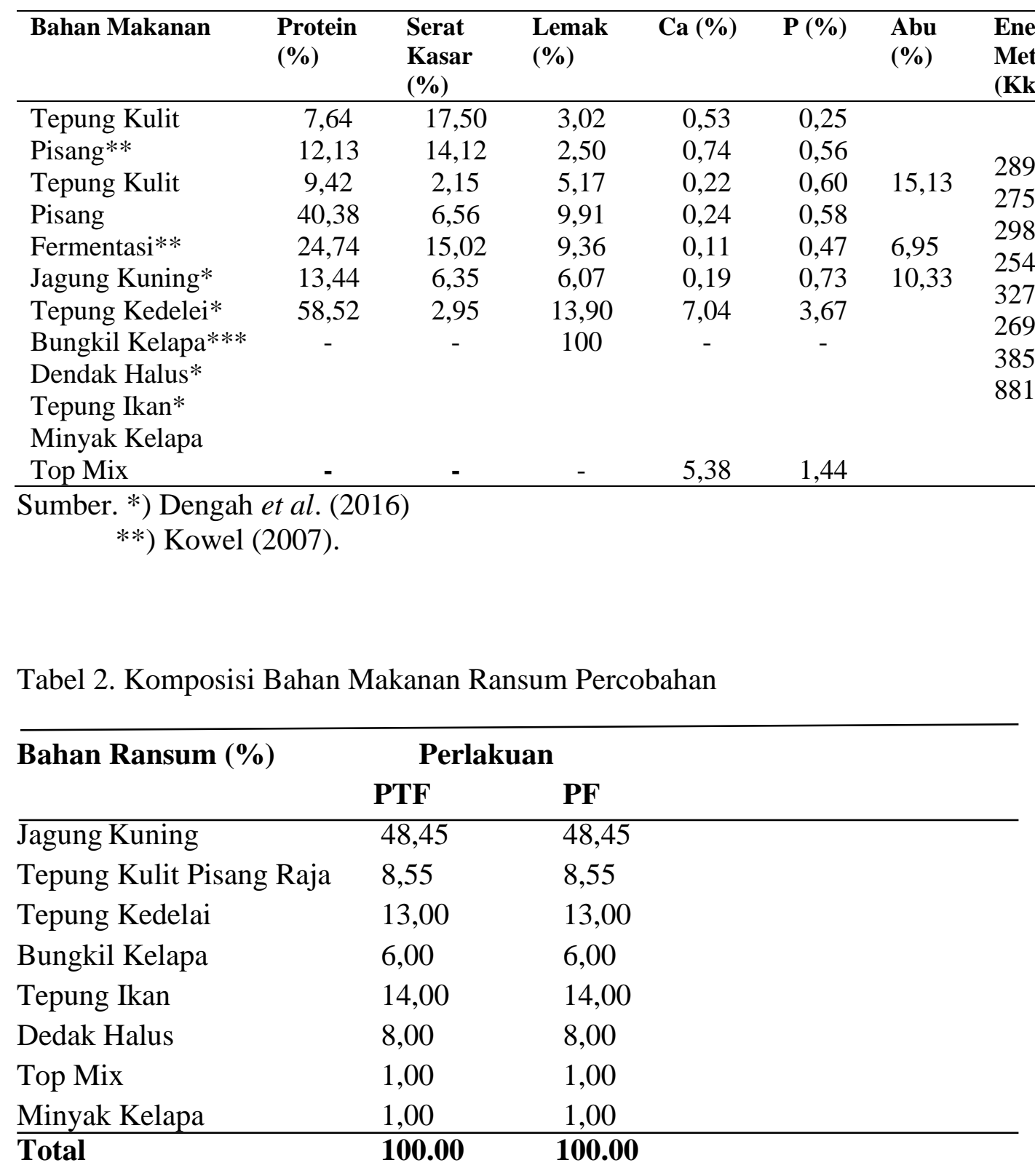

Tabel 3. Komposisi Zat-zat Makanan dan Energi Metabolis Ransum Percobaan.

\begin{tabular}{lll}
\hline Zat-zat makanan & PTF & PF \\
\hline Protein $(\%)$ & 21,44 & 21,83 \\
Serat kasar (\%) & 5,23 & 4,90 \\
Lemak (\%) & 7,04 & 7,00 \\
Ca (\%) & 1,19 & 1,21 \\
P (\%) & 1,21 & 1,03 \\
Energi Metabolis (Kkal/kg) & 2972,29 & 2959,91
\end{tabular}

Dihitung berdasarkan Tabel 1 dan Tabel 2. 
broiler. Pada tahap adaptasi broiler diberikan ransum dasar kemudian diganti dengan ransum perlakuan. Tahap adaptasi pakan perlakuan dilakukan selama 7 hari untuk menggantikan dan membiasakan ternak dengan pakan perlakuan serta menghilangkan pengaruh pakan sebelumnya.

\section{Tahap pengumpulan data}

Tahap pengumpulan data selama 3 hari setelah 7 hari tahap adaptasi,. Hari pertama pengambilan data dihitung berdasarkan waktu pemberian pakan dan ditunggu 1 × 24 jam, setelah itu diambil data dan berat segar ekskreta, kemudian dikeringkan lalu diambil data berat kering masing masing perlakuan dan ulangannya.

Untuk uji parameter yang diukur menggunakan uji t-student (Steel dan Torrie, 1995)

$$
t=\frac{Y}{S y}=\frac{Y-u}{v S^{2} / N}
$$

Keterangan :

$\begin{array}{ll}\mathrm{t} & : \text { Beda perlakuan } \\ \mathrm{u} & : \text { Rata-rata } \\ \mathrm{N} & : \text { Ulangan } \\ \mathrm{Y} & : \text { Total nilai perlakuan } \\ \mathrm{Sy} & : \text { Standar deviasi } \\ \mathrm{S}^{2} & : \text { Varians }\end{array}$

Variabel yang diuji adalah kecernaan bahan kering (KCBK) dan kecernaan bahan organik (KCBO). Perhitungan kecernaan berdasarkan rumus dari Tilman et al., (1998).

$$
\begin{aligned}
& \% \mathrm{KCBK}=\frac{\mathrm{KBK}-\mathrm{BK} E}{\mathrm{KBK}} \times 100 \\
& \% \mathrm{KCBO}=\frac{\mathrm{KBO}-\mathrm{BK} E}{\mathrm{KBO}} \times 100
\end{aligned}
$$

Keterangan:

KBK : Konsumsi bahan kering

KBO : Kecernaan bahan organik

BK E : Bahan kering ekskreta

\section{HASIL DAN PEMBAHASAN}

\section{Pengaruh Perlakuan Terhadap Kecernaan Bahan Kering Tepung Kulit Pisang Raja Tanpa Fermentasi dan Produk Fermentasi}

Rataan kecernaan bahan kering pakan yang mengandung tepung pisang raja pada ayam broiler dapat dilihat pada Tabel 4 yaitu tepung pisang raja tanpa fermentasi sebesar $62,32 \%$ dan produk fermentasi sebesar $71,66 \%$. Berdasarkan uji $t$-student menunjukkan bahwa penggunaan tepung kulit pisang raja produk fermentasi berbeda sangat nyata $(\mathrm{P}<0.01)$ dibandingkan dengan tanpa fermentasi. Hal ini sejalan dengan penelitian dari Abun (2007) bahwa penggunaan kulit pisang raja produk fermentasi meningkatkan kecernaan bahan kering pada ayam broiler. Rataan kecernaan bahan kering pakan yang mengandung tepung pisang raja pada ayam broiler dapat dilihat pada Tabel 4 yaitu tepung pisang 
Tabel 4. Rataan Kecernaan Bahan Kering Tepung Kulit Pisang Raja Tanpa Fermentasi dan Produk Fermentasi.

\begin{tabular}{ccc}
\hline Ulangan & PTF $(\%)$ & PF $(\%)$ \\
\hline 1. & 65,86 & 71,53 \\
2. & 60,44 & 70,26 \\
3. & 60,52 & 71,56 \\
4. & 60,72 & 70,91 \\
5. & 63,32 & 72,76 \\
6. & 63,36 & 72,90 \\
7. & 62,17 & 70,23 \\
8. & 60,56 & 72,53 \\
9. & 64,51 & 71,64 \\
10. & 61,70 & 72,26 \\
\hline Jumlah & 623,16 & 716,58 \\
\hline Rataan & $62,32^{\mathrm{a}} \pm 1,49$ & $71,66^{\mathrm{b}} \pm 0,97$ \\
\hline
\end{tabular}

Keterangan: Superskrip pada baris yang sama berbeda nyata $(\mathrm{P}<0.01)$

raja tanpa fermentasi sebesar $62,32 \%$ dan produk fermentasi sebesar 71,66\%. Berdasarkan uji t-student menunjukkan bahwa penggunaan tepung kulit pisang raja produk fermentasi berbeda sangat nyata $(\mathrm{P}<0.01)$ dibandingkan dengan tanpa fermentasi. Hal ini sejalan dengan penelitian dari Abun (2007) bahwa penggunaan kulit pisang raja produk fermentasi meningkatkan kecernaan bahan kering pada ayam broiler.

Uji t-student diperoleh bahwa bahan kering tepung kulit pisang raja fermentasi nyata berbeda $(\mathrm{P}<0,01)$ lebih tinggi dibandingkan dengan tepng pisang raja tanpa fermentasi. Hal ini menggambarkan bahwa dalam proses fermentasi Rhizopus oligosporus menghasilkan enzim yang dapat mendegradasi selulosa menjadi komponen yang lebih sederhana sehingga nilai kecernaan nutrisi produk fermentasi meningkat. Mokoolang et al. (2017) menyatakan bahwa fermentasi tepung kulit pisang raja menggunakan Rhizopus oligosporus dengan dosis inokulum $0,4 \%$ serta lama fermentasi 96 jam meningkatkan nutrient pakan tersebut. Sejalan dengan pernyataan Achi (2005) dan Buckle et al. (2007) bahwa bahan pakan yang telah difermentasi mempunyai daya cerna lebih 
tinggi karena protein, lemak dan polisakarida telah dihidrolisis mikroba selama proses fermentasi berlangsung.

Kecernaan bahan kering juga dipengaruhi oleh kecernaan dari komponen bahan kering yang terkandung dari bahan itu sendiri seperti protein, karbohidrat (BETN dan serat kasar), lemak, dan abu. Selain itu, disebabkan oleh perubahan kualitas nutrisi pakan karena proses fermentasi (Rompas et al., 2016). Berdasarkan hasil penelitian ini produk fermentasi tepung kulit pisang dengan Rhizopus oligosporus dapat meningkatkan kecernaan bahan kering.

\section{Pengaruh Perlakuan Terhadap Kecernaan Bahan Organik Tepung Kulit Pisang Raja Tanpa Fermentasi dan Produk Fermentasi}

Rataan kecernaan bahan organik pakan yang mengandung tepung kulit pisang raja dapat dilihat pada Tabel 5 yaitu tepung pisang raja tanpa fermentasi sebesar $66,74 \%$ dan produk fermentasi sebesar $73,01 \%$. Berdasarkan hasil uji t-student menunjukkan bahwa penggunaan tepung kulit pisang raja produk fermentasi berbeda sangat nyata $(\mathrm{P}<0.01)$ dibandingkan dengan tanpa fermentasi. Artinya penggunaan produk fermentasi tepung kulit pisang raja dengan Rhizopus oligosporus dapat meningkatkan kecernaan bahan organik. Uji t-student diperoleh bahwa bahan organik tepung kulit pisang raja fermentasi nyata berbeda $(\mathrm{P}<0,01)$ lebih tinggi dibandingkan dengan tepung kulit pisang raja tanpa fermentasi. Hal ini terjadi karena pada proses fermentasi tepung kulit pisang raja terjadi peningkatan protein serta

Tabel 5. Rataan Kecernaan Bahan Organik Tepung Kulit Pisang Raja Tanpa Fermentasi dan Produk Fermentasi.

\begin{tabular}{|c|c|c|}
\hline Ulangan & PTF (\%) & $\mathrm{PF}(\%)$ \\
\hline 1 & 68.62 & 74,47 \\
\hline 2 & 65.56 & 70,25 \\
\hline 3 & 66.56 & 74,43 \\
\hline 4 & 65.54 & 70,57 \\
\hline 5 & 67.62 & 73,74 \\
\hline 6 & 68.65 & 75,90 \\
\hline 7 & 65.01 & 71,81 \\
\hline 8 & 66.35 & 73,41 \\
\hline 9 & 65.12 & 73,24 \\
\hline 10 & 68.32 & 73,31 \\
\hline Jumlah & 667,35 & 730,13 \\
\hline Rataan & $66,74^{a} \pm 1,46$ & $73,01^{b} \pm 1,79$ \\
\hline
\end{tabular}

Keterangan: Superskrip pada baris yang sama berbeda nyata $(\mathrm{P}<0.01)$ 
penurunan serat kasar. Perubahan nilai dan kualitas nutrien ini menyebabkan lebih meningkatnya nilai guna tepung kulit pisang raja produk fermentasi dalam alat pencernaan ayam. Hal ini didukung oleh pendapat Tillman et al. (1998) yang mengemukakan bahwa faktor yang mempengaruhi kecernaan bahan organik adalah kandungan zat nutrisi dalam ransum. Kisaran kecernaan bahan organik dalam penelitian ini lebih tinggi dibandingkan hasil penelitian kecernaan bahan organik oleh Mangisah et al. (2009) yang berkisar antara 52, 81\%-72,41\%. Kecernaan bahan organik memiliki korelasi positif atau berbanding lurus dengan kecernaan bahan kering artinya semakin tinggi kecernaan bahan organik maka semakin tinggi nilai kecernaan bahan kering atau sebaliknya. Hal ini sesuai dengan pendapat Abun (2007) yang menyatakan bahwa KcBO berbanding lurus dengan KcBK, KcBK semakin tinggi maka $\mathrm{KcBO}$ semakin tinggi. Sutardi (1980) melaporkan bahwa peningkatan kecernaan bahan organik sejalan dengan meningkatnya kecernaan bahan kering, karena sebagian besar komponen kecernaan bahan kering terdiri atas kecernaan bahan organik sehingga faktor-faktor yang mempengaruhi tinggi rendahnya kecernaan bahan kering akan berpengaruh juga terhadap tinggi rendahnya kecernaan bahan organik. Artinya penggunaan serat kasar dalam ransum pada penelitian ini masih dalam batas yang ditentukan. Hal ini sesuai dengan pernyataan Kartadisastra (1994) bahwa penggunaan maksimum dalam ransum ayam unggas tidak lebih dari $5 \%$. Jika persentase serat kasar berlebih dalam ransum maka akan menghambat penyerapan zat-zat makanan dalam tubuh ayam broiler.

\section{KESIMPULAN}

Berdasarkan hasil dan pembahasan dapat disimpulkan bahwa penggunaan tepung kulit pisang raja produk fermentasi sebesar 8,55\% dalam ransum memberikan hasil yang lebih baik terhadap kecernaan bahan kering dan bahan organik dibandingkan dengan tanpa fermentasi.

\section{DAFTAR PUSTAKA}

Achi, O. K. 2005. Traditional fermented protein condiments in Nigeria. African Journal of Biotechnology 4(13): 1612-1621.

Abun. 2007. Pengukuran Nilai Kecernaan Ransum yang Mengandung Limbah Udang Windu Produk Fermentasi pada Ayam Broiler. Skripsi. Fakultas Peternakan Universitas Padjajaran, Bandung.

Buckle, K.A., R.A. Edward, G.H. Fleet dan Wootton. 2007. Ilmu Pangan. Edisi ke-4. Terjemahan: 
Hari Purnomo dan Adiono. UIPress. Jakarta.

Djapili, D., F. Wolayan, I. Untu dan H. Liwe. 2016. Pengaruh penggantian sebagai jagung dengan tepung kulit pisang raja (Musa Paradisiaca) dalam ransum terhadap Performan broiler. Jurnal Zootek 36(1): 158166

Dengah, S. P., J. F. Umboh, C. H. Rahasia dan Y. H. S. Kowel. Tepung maggot (Hermetia illucens) dapat mengantikan tepung ikan sebesar $75 \%$ atau $11,25 \%$ dalam ransum tanpamemberikan efek buruk terhadap efisiensi penggunaan makanan ayam broiler. Jurnal Zootek 36(1): 51-60

Kartadisastra, H.R. 1994. Pengelolaan Pakan Ayam Kiat Meningkatkan Keuntungan Agribisnis Unggas. Yogyakarta: Kanisius.

Kowel, Y.H.S. 2007. Pengaruh Penggunaan Limbah Minyak Pengalengan Ikan dalam Ransum Terhadap Efisiensi Biologis dan Kualitas Karkas Broiler. Tesis. Universitas Sam Ratulangi. Program Pascasarjana. Manado.

Mangisah, I., B. Sukamto dan M. H. Nasution. 2009. Implementasi daun eceng gondok fermentasi dalam ransum itik. J. Indon. Trop. Anim. Agric. 34(2):127-132.
Manorek, J. M., F. R. Wolayan, I. M. Untu dan H. Liwe. 2017. Biokonversi Kulit Pisang Raja (Musa paradisiaca) dengan Rhizopus oligosporu terhadap perubahan kandungan serat kasar dan lemak. Zootec 38(1): 6676.

Mokoolang, F. R Wolayan, M. L Imbar, W. L. Toar. 2017. biokonversi kulit pisang raja (musa paradisiaca) dengan rhizopus ligosporus terhadap perubahan kandungan bahan kering, bahan organik dan protein kasar. Jurnal Zootek 38(1), 56-65.

Rompas, R., .B Tulung, J. S. Mandey, M. Regar. Penggunaan Eceng Gondok (Eichhornia Crassipes) terfermentasi dalam ransum itik terhadap kecernaan bahan kering dan bahan organik. Jurnal Zootek 36(2): 372-378.

Steel, R.D. dan J.H. Torrie.1995. Prinsip dan Prosedur Statistik. PT. Gramedia. Pustaka Jakarta.

Sutardi, T. 1980. Landasan Ilmu Nutrisi. Jilid I Departemen Ilmu Makanan Ternak. Fakultas Peternakan. Institut Pertanian Bogor.

Tillman, A. D., H. Hartadi, S. Reksohadiprojo, S. Prawirokusumo dan S. Lebdosoekojo. 1998. Ilmu Makanan Ternak Dasar. Gadjah Mada University Yogyakarta 